P. E. Herchanivska, Doctor of Cultural Studies, Professor

The National Academy of Culture and Arts

9, Lavra Street, Kyiv, 01015, Ukraine

\title{
MODEL OF CULTURAL RESEARCH IN THE PARADIGM OF THEORY OF SYSTEMS
}

The article is devoted to the development of culturological studies methodological model of the socio-cultural phenomenon based on the theory of systems principles. The analysis is based on a conceptual paradigm: Sociocultural object is a system consisting of separate parts, interconnected by certain relationships; the system is in continuous development and interaction with the external environment.

The algorithm of system analysis contains: understanding the basic purpose and functions of the system; the choice of most optimal variant for partitioning system on components (subsystem, elements); introducing of the hierarchy of parts in the structure of the system; detection of function of each subsystem and linkages between them; definition of the system connections with the environment (or other systems); study of the nature of the variability of the system, of its ability to development and adaptation to the environment. The classification of the sociocultural systems depends on the selected criteria, for example: on the nature of the items, their origin, the variability of propertie, the degree of difficulty, the attitude to the environment, etc.

The article reveals the features of system analysis in cultural studies, as well as the potential of the theory of systems in the field of culturology for solving theoretical and practical problems. In the view of the synergetic model, the algorithm of the process of self-organization of the sociocultural system and the mechanisms governing this process are analyzed. The article shows that the self-organization of a sociocultural system is a nonlinear process that is a sequence of phase transitions from an equilibrium state through a nonequilibrium phase and dissipation to bifurcation and relaxation of the system. The process of intercultural interaction is considered through the prism of system analysis. The article shows that the openness of the socio-cultural system is a necessary and indispensable condition for intercultural interaction.

Key words: theory of systems, system analysis, cultural system, synergetic model, intercultural interaction.

Удк 111.1/.852:17

В. Ю. Головей, д-р філос. наук, проф. Східноєвропейський національний університет ім. Лесі Українки пр. Волі, 13, м. Луцьк, 43025, Україна v_golovey@ukr.net

\section{КУЛЬТУРОТВОРЧИЙ ПОТЕНЦІАЛ САКРАЛЬНОГО ДОСВІДУ: ТЕОРЕТИКО-МЕТОДОЛОГІЧНИЙ АНАЛІЗ}

Метою статті є аналіз культуротворчого потенціалу сакрального досвіду та висвітлення основних методологічних підходів до його дослідження. Сакральний досвід експлікується як досвід співвіднесення із абсолютним виміром буття, його переживання й осмислення. Поняття "досвіду священного" окреслює культурно-організований простір, який набуває специфічної для кожної культури форми і структурується як осмислений і облаштований ієрархічний світ, сповнений духовно-символічних значень. Стверджується, що досвід священного вирізняється онтологічним змістом і характером. Це досвід символічних актів трансцендування, які утворюють онтологічний горизонт буття. Водночас - це досвід культуротворення і самотворення, в якому формуються смисложиттєві засади людського існування, розкривається й утверджується людська сутність. Втрата потужності і конститутивної сили сакрального виміру трактується як прояє своєрідного "ослаблення буття", деонтологізації культури, що супроводжується вивільненням симулятивних та деструктивних потенцій і призводить до зниження інтенсивності та якості культурного розвитку.

Ключові слова: сакральний досвід, культура, сакральне, профанне, релігійний, секулярний.

Постановка проблеми. Якщо у природничих науках поняття "досвід" набуло чіткості й визначеності, то в гуманітарних дослідженнях досить часто простежується упередженість стосовно правомірності використання понять "релігійний досвід", "сакральний досвід", "містичний досвід" як наукових термінів. I на це $€$ вагомі причини. "Поняття досвіду належить, - на думку Г.- Ґ. Ґадамера, хоч як парадоксально це звучить, - до найменш з'ясованих понять із числа тих, що ми маємо в нашому розпорядженні. ...Дійсний недолік попередньої теорії досвіду... полягає саме в тому, що вона цілком зорієнтована на науку й тому втрачає з поля зору внутрішню історичність досвіду" [3, с. 321-322]. Безумовно, концепція досвіду як заснованого на практиці чуттєво-емпіричного пізнання дійсності не відповідає ситуації в деяких важливих ссрерах людської духовної діяльності - історичній і філософській, естетичній і релігійній. Стосовно ж цих сфрер досвіду проблематично створити єдину концептуальну основу, що зумовлює потребу експлікації понять, які б означували різновиди духовного досвіду. Поглиблення розуміння духовного досвіду від його джерел і в його головних проявах означає просування вперед наших загальних знань про людину. Саме тому ця проблематика є важливим напрямком гуманітарних досліджень.

Аналіз досліджень і публікацій. Важливі аспекти досліджуваної проблематики висвітлені у відомих роботах В. Джеймса, В. Соловйова, С. Франка, Е. Кассірера, М. Мамардашвілі, О. Розенштока-Хюссі, П. Тілліха, $€$. Торчинова, в яких розглядаються типологія та специифріка релігійного досвіду, його органічний зв'язок із такими символічними формами духовної культури, як мова, міфологія, мистецтво. Онтологічний вимір релігійно-містичного досвіду аналізується в наукових розвідках С. Хоружого. Поняття "внутрішнього", або "граничного", досвіду концептуалізується Ж.Батаєм і М. Фуко; "граничний досвід" у цьому дискурсі безпосередньо співвідноситься 3 поняттями "трансгресія" та "суверенність". Серед сучасних українських досліджень різновидів духовного досвіду слід передусім виділити ґрунтовні доробки М. Мінакова, О. Павлової та ін. Що ж до поняття "сакрального досвіду", то до сьогодні воно не отримало належної наукової концептуалізації, яка б надала можливість здійснити його поглиблену експлікацію.

Метою статті $€$ аналіз культуротворчого потенціалу сакрального досвіду та висвітлення основних методологічних підходів до його дослідження.

Виклад основного матеріалу дослідження. Розмірковування про сутність сакрального досвіду слід починати з більш загального питання: яким чином ми можемо бачити в речах і поза ними відносини, які емпіричний досвід сам по собі не здатен там виявити? Слід визнати, що в таких випадках ми маємо справу з безпосередніми даними духовного досвіду. Духовне начало - принципово відмінна від усіх емпіричних характеристик якість, яка визначає людську сутність. Людина $\epsilon$ людиною саме тому, що вона $\epsilon$ чимось більшим, ніж емпірично-природна істота. Трансцендентне виявляється в досвіді, проте цей досвід особливий, якісно відмінний від емпіричного. У ньому "об'єктивна, надіндивідуальна реальність дана нам не у фрормі предметної дійсності ззовні як об'єкт, що протистоїть як трансцендентна реальність "суб'єкту" і

() Головей В. Ю., 2017 
його зовнішньому світу, а у формі реальності, яка присутня в нас самих, споріднена з нами зсередини й нам розкривається. Такою $є$ реальність Бога, як вона дана нам у первинному містичному досвіді - незалежно від того, як ставлення людини до Бога виражається в подальшій рефлексії, у похідних богословських доктринах", - зазначав С. Франк [11, с. 72-73].

Як відомо, уперше на необхідності якісної диференціації досвіду наголосив Р. Бекон, який виділив два різновиди досвіду - емпіричний і надемпіричний (містичний). Значну увагу поглибленій експлікації цієї категорії приділили Дж. Локк, І. Кант, Гегель. Проблематизація поняття "досвід" у класичній німецькій фрілософії уможливила його перетворення з інструментального поняття на одне з основних понять західної фрілософії. Зокрема, трансцендентальне тлумачення досвіду у фрілософії Канта, засноване на думці про те, що досвід $є$ цілісністю спонтанно-рецептивних спроможностей суб'єкта, створило епістемологічну основу для аналізу відповідних теорій. Тут фрілософське вивчення досвіду отримало настанову мислити як підстави власної можливості, так і умови тотальності мисленнєвого простору в поняттях, які забезпечують найменшому досвідному актові присутність у ньому всієї структури досвіду взагалі [9].

Згідно 3 авторитетною думкою Гегеля, "цей діалектичний рух, який здійснюється свідомістю у самій собі, як відносно свого знання, так і щодо свого предмета - оскільки для нього виникає з цього новий істинний предмет, $\epsilon$, власне кажучи, тим, що називається досвідом" [4, с. 48]. Отже, структура досвіду, за Гегелем, полягає в повороті свідомості, а сам досвід $є$ ії діалектичним рухом, скерованим на висвітлення сущого в його істині. Здійснюючи цей діалектичний рух у процесі усвідомлення чогось нового, свідомість відкриває нові горизонти пізнання, до меж яких і розширюється досвід.

Безумовно, досвід $є$ результатом практичної і теоретичної діяльності, багатогранної взаємодії людини та світу. Він об'єктивується в предметній і мовній фрормах, у цінностях культури. Однак досвід - це не тільки те, що здобувають і нагромаджують у процесі практики та світопізнання, а й водночас те, що переживають. Ця подвійність досвіду найбільш повно експлікована у феноменології Е. Гуссерля у контексті аналізу досвіду інтенціональності $з$ приводу конституювання структур трансцендетальної інтерсуб'єктивності. На думку Гуссерля, за посередництвом такого досвіду "его містить у собі й може завжди заново формувати такі нові інтенціональності, які наділені буттєвим смислом, завдяки чому воно повністю трансцендує своє власне буття... Йдеться про те, щоб вивчити цей досвід та інтенціонально розкрити спосіб, яким він набуває смислу" [5, с. 208-209]. У феноменології та герменевтиці особливо наголошується на недопустимості недооцінки онтологічного виміру досвіду, адже цей вимір визначається буттєвою улаштованістю досвіду як відкритої структури смислопородження.

У методологічному плані важливою $є$ і концепція Е. Кассірера, сфокусована на визначенні первинного щабля досвіду в культурних формах. Філософрія символічних форм Е. Кассірера визнає культурний досвід за фундаментальний, на підґрунті якого можуть бути описані будь-які інші регіони досвіду. Виражальна функція досвіду визначена як принцип культури, який полягає в необмеженості історичних форм синтезу різноманітних виражальних можливостей, притаманних людському духові та рецептивно-спонтанній даності людського життя [7, с. 26].
Передусім потрібно визначити, який же зміст ми вкладаємо в поняття "досвід священного", у чому полягає його специфіка. Сакральний досвід - це досвід співвіднесення зі священним, абсолютним виміром буття, досвід одкровення, який має універсальний людський характер. Це також досвід творення символів священного, його переживання й осмислення. Поняття "досвіду священного" окреслює культурно-організований простір, який набуває специфічної для кожної культури форми і структурується як осмислений і облаштований ієрархічний світ, сповнений духовно-символічних значень. У цьому просторі люди вступають у комунікацію особливого роду, виконуючи особливі ролі та функції: шамана, чаклуна, жерця, пророка, містика, відлюдника, паломника й навіть жертви. Такий досвід може мати різнопланові форми вияву: екстатичні, споглядально-медитативні, тілесно-експресивні, раціонально-рефлективні тощо.

На нашу думку, досвід священного передусім вирізняється своїм онтологічним змістом і характером. Це досвід символічних актів трансцендування, які утворюють онтологічний горизонт буття. Особливістю людської присутності у світі $€$ те, що вона виступає за межі сущого. Таке виступання за межі сущого Гайдеггер і називає трансценденцією [13, с. 22]. Трансцендування - особлива, єдина свого роду дія онтологічного начала; його "завершеність" i "актуалізація" (якщо взагалі про них можна говорити) також особливого роду. Вони означають актуалізований у повноті, доконаний перехід в інший онтологічний горизонт, з іншими фундаментальними предикатами.

Пауль Тілліх уважає за необхідне виділити два головних елементи, які визначають будь-який досвід священного. Один із цих елементів - це хронотопос присутності, тобто присутність священного тут і тепер. Сакральне освячує місце й реальність свого прояву. Воно охоплює душу своєю чарівною і водночас загрозливою силою. Воно вривається в повсякденну реальність, потрясає ії, підбурює її до виходу за власні межі в екстатичний спосіб. Воно задає правила, за якими тільки й можна до нього наблизитися. Щоб переживатися в досвіді, священне має бути присутнім і відчуватися як присутнє. Водночас воно може виступати і як святе, тобто вимагати особистого прагнення ідеалу святості в смислі довершеності, справедливості й любові. Святості, яка стверджує моральний обов'язок на рівні категоричного імперативу, можна набути лише в сакральному досвіді. Перший структурний елемент Тілліх називає онтологічним (священність сущого), а другий - моральнісним (особистісна святість) і наголошує, що "в досвіді священного онтологічний і моральнісний елементи нерозривні по суті" [10, с. 178].

Досвід священного ґрунтується на безпосередньому переживанні вічності й тотальності буття як живої реальності. Такий досвід є "досвідом буття", вираженням первинної буттєвої настанови, глобальної антропологічної орієнтації. Він інтегрує духовні домінанти в систему орієнтування людини у світі й у систему розуміння самої себе. Маючи активну формотворчу, духовноенергійну природу, цей досвід виступає провідним фрактором сапієнтизації, духовного становлення людини й культури, що забезпечується буттєвою улаштованістю досвіду як відкритої структури смислопородження. Тому основними функціями такого досвіду $є$ генеративна, або породжувальна, а також анагогічна (від гр. anagogicus поступове сходження), тобто така, яка підносить духовно від чуттєвого до надчуттєвого виміру. Сакральний досвід імпліцитно присутній в основі всіх вагомих 
людських починань, сприяє формуванню самої людськості. Цей досвід пронизує всю історію, як вертикаль, як вісь земна, що завершується в трансцендентному вимірі - там, де людина ввіряє себе абсолюту (Богові, буттю, благу, вічності тощо). Можна сказати, що будьяка реалізована антропологічна стратегія або модель має своїм генеруючим ядром певний сакральний досвід. Сферу сакрального досвіду становлять явища не стільки унікальні та надзвичайні, скільки такі, які можна назвати онтологічно пограничними, коли йдеться про подолання кордонів емпіричної реальності та вихід на межі онтологічного горизонту. На думку С. Хоружого, у такому досвіді здійснюється "онтологічний вихід", своєрідна трансформація, "перевершення фундаментальних предикатів наявного буття" [14, с. 198]. Тобто вимір сакрального досвіду можна трактувати як горизонт онтологічно граничних явищ, який ототожнюється 3 горизонтом актів трансцендування. У цьому контексті доречними будуть зіставлення визначень цих духовних станів із деякими спорідненими поняттями сучасної фрілософської думки. "Пограничні ситуації", про які говорить екзистенціалізм, не мають із ними особливої близькості, оскільки залишаються в горизонті наявного буття. Їм властива скоріше психологічна, ніж онтологічна "граничність". Однак цілком виправданими будуть зіставлення сакрального досвіду із поняттями "внутрішнього", або "граничного", досвіду як досвіду "неможливого" у фрранцузькій фрілософії XX ст. (Ж. Батай, М. Фуко).

У теоретичних концепціях цих фрілософрів "граничний" досвід характеризується максимально інтенсивним зусиллям подолання наявного образу буття, постановкою його під питання. "Досвід - це палка і тужлива постановка під питання (на випробування) всього, що відомо людині про справу буття", - зазначає Ж. Батай [1, с. 18]. На думку М. Фуко, граничний досвід - це спроба досягнути максимуму інтенсивності й максимуму неможливості. "У цьому розумінні внутрішній досвід $€$ цілком досвідом неможливого (оскільки неможливе $є$ тим, на що він скерований і що його конституює)" [12, с. 115]. Ідеться про глибинний вимір нашого досвіду, який Батай називає "сокровенністю". Такий досвід переживається за відсутності суб'єктно-об'єктних відносин, які зумовлюють розрив - свідому дистанцію між "Я" і "Ти" (що, за М. Бубером, рівнозначно переходу на рівень "Я" - "Воно"). Прагнення людини до цілісності, "пошуки втраченої сокровенності" визначають, на думку Батая, саму суть сакрального досвіду.

Особливої гостроти і трагічності досвід священного набуває в умовах смерті Бога, яку не слід розуміти як кінець його історичного панування або ж як остаточне свідчення його неіснування. "Ця смерть утворює віднині усталений простір нашого досвіду" [12, с. 115]. Вона позбавляє наше існування межі Безмежного і приводить до такого досвіду, в якому вже ніщо не може провіщати про зовнішнє буття, а отже, до досвіду внутрішнього й суверенного. Смерть Бога - це жертвоприношення, у якому жертвують усім. Це той діалектичний рух, словами Гегеля, той "поворот свідомості", що скеровує нас від обмеженого правилами й заборонами позитивного світу до світу негативного, який руйнує межі та саморуйнується в акті ексцесу, зловживання, надмірності, богохульства, святотатства - в акті трансгресії.

Поняття "граничний досвід" у цьому дискурсі співвідноситься з поняттям трансгресії (з лат. - перехід, переступання меж). Ж. Батай зазначав, що трансгресія не має нічого спільного із примітивною сваволею: "вона відкриває доступ по той бік границь, яких зазвичай прийнято дотримуватись, проте зберігає ці границі" [2, c. 536]. Трансгресія порушує, але не руйнує межу між сакральним і профанним. Граничний досвід можливий лише для людини, яка радикально ставить під питання саму себе й межі можливого. На думку М. Фуко, шлях до священного, до божественного пролягає саме через трансгресію: "...вона заодно з божественним, або, точніше, виходячи з тої межі, що позначає священне, вона відкриває простір, у якому розгортається божественне" [12, с. 119]. У такому розумінні трансгресія іманентна самій структурі сакрального, містичного досвіду як повноцінний онтологічний акт, у якому актуально долається, перевершується біологічна природа людини.

Саме на цьому шляху людина може досягнути справжньої суверенності, того "граничного досвіду", у якому проявляє себе абсолютний суб'єкт. Це вищий ступінь свободи, наскільки він взагалі можливий в реальній дійсності. Через амбівалентність сакрального суверенними можуть бути не тільки монах або аскет, які в екстазі упиваються Богом, а й людина "суверенного мистецтва", митець-бунтар, фрілософ-бунтар на зразок Війона, маркіза де Сада, Бодлера, Ніцше або Батая, які перетворили своє життя у свідоме порушення заборон, у саморозтрату, саморуйнування всупереч успішному та прибутковому самоствердженню. Однак це вже доволі специфічний досвід сакрального - поза релігією, без догматів і офріційних ритуалів, - це екзистенціальноособистісне, максимально напружене, естетично-насичене й водночас кощунне переживання граничних засад людського існування. У такому кощунному, богоборчому досвіді відроджується первісна повнота сакрального в його амбівалентності й виражається життєвий протест духовної істоти проти закоснілості, буденності, формальності нормативних ритуалів, які провокують нещирість, подвійне життя, затаврувавши поняттям "гріх" несамовиті поривання людської душі.

Для людини, для людської культури сакральний досвід $€$ долученням до динамічної вічності (термін М. Мамардашвілі), що потребує надзвичайних зусиль, вертикалізму, "бодрствования". Мамардашвілі виразно акцентував цей аспект в курсі лекцій, опублікованих під назвою "Естетика мислення", у контексті міркувань про "покоління, яке не проходить", тобто таке покоління, яке не проґавило історичну мить, мужньо відповіло на іiї виклик звитягою і творчими звершеннями, започаткувавши нові культурні обрії, новий світ. Це сучасники кайросу, які доводили свої дії до довершеної форми, коли стани часу та їхніх душ перетворювалися на стани історії. На думку фрілософа, "не проходить покоління, яке складається 3 людей, здатних тримати думку й час, - адже потік тече, все уносячи, - щоб тим самим скувати його вічністю..." [8, с. 209]. Скувати потік вічністю здатна тільки вертикальна людина, яка "бодрствує", не спить. Саме такі люди вершать історіали, моменти інтенсивного часу - "акти, які $€$ не станами часу або душі, а станами історії і здатні потім підштовхувати людину в напрямку її піднесення над своєю власною тваринною натурою" [8, с. 229].

Вимір інтенсивного часу, динамічної вічності відкриває людина, яка співвідносить себе з граничним. Таке співвіднесення можливе лише за допомогою символів. Люди, які руйнують або втрачають символи (дуже часто через власну нездатність або небажання підтримувати їх живими, дієвими), втрачають "органи" розуміння і конституювання смислів, а отже, здатність до живого, справжнього, повноцінного культуротворення. Зі заміною символів симулякрами, а символічної репрезентації симуляцією культура перетворюється на посткультуру. 
Співвідносячись із сакральною подією, ми долучаємося до динамічної вічності, стаємо учасниками божественної і людської драми, яка триває споконвічно. У цьому контексті Мамардашвілі нагадує фразу Паскаля, яка, на його думку, містить у собі цілу онтологію світу: "Агонія Христа буде тривати до кінця світу, і увесь цей час - не можна спати". Звичайно, цей вислів не слід розуміти буквально, як емпіричний рецепт поведінки. Мамардашвілі виділяє тут два таких моменти: "Перше - існують фундаментальні онтологічні акти, які ми не можемо вважати такими, що відбулися, завершеними, і друге - вони весь час відбуваються і ми не повинні спати, тому що від цього залежить, у яку сторону, в якому напрямку піде світ" [8, с. 210]. Людина прагне повноти свого потенційного існування, а також реалізувати себе в термінах людської гідності. Але людська гідність не є якістю, яка може бути здобута назавжди. Її потрібно весь час здобувати заново. "Ось цей клубок речей умовно можна назвати динамічною вічністю, тому що ми, як смертні істоти, не можемо перебувати всередині цієї вічності, не здійснюючи зусиль" [8, с. 208].

Парадоксальність досвіду священного - у тому, що він виводить на рівень актуальної безкінечності, неможливої як сукупність завершених дій (страждання прикутого Прометея, агонія розп'ятого Христа, як і його народження, не $є$ завершеними актами, вони тривають). Якщо й існують абсолютні смисли, то саме в цьому просторі просторі актуальної безкінечності. На феноменальному рівні вони репрезентовані в сакральних символах, творення і живлення яких (а вони живі тільки в постійному співвіднесенні з граничним, абсолютним) вимагає від людини максимальної напруги ї̈ творчих сил. Саме вихід (прорив) на рівень абсолютних смислів і відкриває людині простір, у якому можливе духовне самотворення, самозародження. Культура не має кумулятивного ефекту; не існує культурних генів, які б можна було успадкувати фізично. Кожна людина від ії фізичного народження, кожне покоління, етнос, кожна культура мають пройти свій шлях "народження згори", свій шлях плекання власної гідності, духовного, культурного самоствердження.

Висновок. Отже, поняття досвіду священного окреслює культурно-організований простір, який набуває специфрічної для кожної культури фрорми і структурується як особливий, осмислений і облаштований ієрархічний світ, сповнений духовно-символічних значень. Через досвід священного стає досяжним основоположний стан людського буття, в якому людина приходить до повноти власної сутності. Сакральний досвід - це досвід духовного освоєння світу через символічне співвіднесення з Абсолютом, зі смисложиттєвими домінантами людського буття, які наділяються абсолютним, священним, статусом. Водночас це досвід духовного процесу трансцендування, у якому розкривається i справджується сама природа людини. Він ґрунтується на безпосередньому переживанні вічності й тотальності буття як живої реальності. У потоці такого досвіду, розміченого символами священного, відбувається духовне становлення людини та творення культури.

\section{СПИСОК ВИКОРИСТАНИХ ДЖЕРЕЛ}

1. Батай Ж. Внутренний опыт / Ж. Батай ; [пер. с фр. С. Л. Фокин]. - СПб. : Аксиома, Мифрил, 1997. - 336 с.

2. Батай Ж. Эротика / Ж. Батай ; [пер. с фр. Е. Д. Гальцева] // "Проклятая часть": Сакральная социология / Ж. Батай. - М. : Ладомир, 2006. - С. 491-701.

3. Ґадамер Г.-Г. Істина і метод. У 2-х Т. - Т. 1: Герменевтика I / Г.-ґ. Ґадамер; [пер. з нім. О. Мокровольський] - К. : Юніверс, 2000. - 464 с.

4. Гегель Г.-В.-Ф. Феноменология духа / Г.-В.-Ф. Гегель. - СПб. : Наука, 1999. - 443 с.

5. Гуссерль Э. Картезианские размышления / Э. Гуссерль ; [пер. с нем. Д. В. Скляднев]. - СПб. : Наука, 1998. - 316 с.

6. Джемс У. Многообразие религиозного опыта / У. Джемс ; [пер. с англ. У. С. Элбакян] // Мистика. Религия. Наука : Антология. - М. : Канон+, 1998. - С. 149-173.

7. Кассирер Э. Логика наук о культуре / Э. Кассирер ; [пер. с нем. и коммент. С. О. Кузнєцов и Б. Вимер] // Избранное. Опыт о человеке / Э. Кассирер. - М. : Гардарика, 1998. - С. 7-154.

8. Мамардашвили М. К. Эстетика мышления / М. К. Мамардашвили. - М. : Московская школа политических исследований, 2000. -416 с

9. Мінаков М. Історія поняття досвіду / М. Мінаков. - К. : Парапан, 2007. $-380 \mathrm{c}$.

10. Тиллих П. Динамика веры / П. Тиллих ; [пер. с англ. Т. И. Вевюрко] // Избранное: Теология культуры / П. Тиллих. - М.: Юрист, 1995. - C. 132-215.

11. Франк С. Л. Духовные основы общества / С. Л. Франк. - М. : Республика, 1992. - 511 с

12. Фуко М. О трансгрессии / М. Фуко. // Танатография эроса. Спб. : Мифррил, 1994. - С. 111-131.

13. Хайдеггер М. Что такое метафизика / М. Хайдеггер ; [пер. с нем., вступ. ст. и коммент. В. В. Бибихин] // Время и бытие: Статьи и выступления. - М.: Республика, 1993. - С. 16-27.

14. Хоружий С. С. К феноменологии аскезы / С. С. Хоружий - М. : Изд-во гуманитарной литературы, 1998. - 352 с.

\section{REFERENCES}

1. Bataj, Zh. (1997). Vnutrennij opyt [Internal Experience]. St. Petersburg, Aksioma, Mifril.

2. Bataj, Zh. (2007). Erotika [Eroticism]. "Proklataja chast"': Sakral'naja sociologija. Moskow, Ladomir.

3. Gadamer, G.-r. (2000). Istyna i metod [Truth and Method]. Vol. 1. Kyiv, Junivers.

4. Gegel', G.-V.-F. (1999). Fenomenologija duha [Phenomenology of the Spirit]. St. Petersburg, Nauka.

5. Gusserl', E. (1998). Kartezianskie razmyshleniia [Cartesian Reflections]. St. Petersburg, Nauka.

6. Dzhems, U. (1998). Mnogoobrazie religioznogo opyta [The Varieties of Religious Experience]. In Mistika. Religija. Nauka: Antologija. Moskow, Kanon. 149-173.

7. Kassirer, E. (1998). Logika nauk o kul'ture [The Logic of the Sciences of Culture]. In Izbrannoe. Opyt o cheloveke [Favorites. The Logic of the Humanities]. Moskow, Gardarika.

8. Mamardashvili, M. K. (2000). Estetika myshleniia [Aesthetics of Thinking]. Moskow, Moskovskaja shkola politicheskih issledovaniy.

9. Minakov, M. (2007). Istoriia poniattia dosvidu [History of the Concept of Experience]. Kyiv, Parapan.

10. Tillih, P. (1995). Dinamika very [The Dynamics of Faith]. In Izbrannoe: Teologija kul'tury [Favorites: Theology of Culture]. Moskow, Jurist.

11. Frank, S. L. (1992). Duhovnye osnovy obshhestva [Spiritual Foundations of Society]. Moskow, Respublika.

12. Fuko, M. (1994). O transgressii [About Transgression]. In Tanatografija erosa [Tanatography of Eros]. St. Petersburg, Mifril.

13. Haidegger, M. (1993). Chto takoe metafizika [What is Metaphysics]. In Vremia i bytiie: Stat'i i vystupleniia [Being and Time: Articles and Speeches]. Moskow, Respublika. 16-27.

14. Horuzhii, S. S. (1998). K fenomenologii askezy [To the Phenomenology of Asceticism]. Moskow, Izd-vo gumanitarnoj literatury.

Надійшла до редколегії 26.05.17

В. Ю. Головей, д-р филос. наук, проф.

Восточноевропейский национальный университет им. Леси Украинки

проспект Воли, 13, г. Луцк, 43025, Украина

\section{КУЛЬТУРОТВОРЧЕСКИЙ ПОТЕНЦИАЛ САКРАЛЬНОГО ОПЫТА: ТЕОРЕТИКО-МЕТОДОЛОГИЧЕСКИЙ АНАЛИЗ}

Целью статьи является анализ культуротворческого потенциала сакрального опыта и освещение основных методологических подходов к его исследованию. Сакральный опыт эксплицируется как опыт соотнесения с абсолютным измерением бытия, его переживания и осмысления. Понятие "опыта священного" определяет культурно-организованное пространство, которое приобретает специфическую для каждой культуры форму и структурируется как осмысленный иерархический мир, наполненный духовно-символическими значениями. Это опыт символических актов трансцендирования, которые образуют онтологический горизонт бытия. В то же время - это опыт культуротворчества и самосозидания, в котором формируются смысложизненные основы человеческого существования, раскрывается и 
утверждается человеческая сущность. Потеря мощности и конститутивной силы сакрального измерения трактуется как проявление своеобразного "ослабления бытия", деонтологизации культуры, сопровождающейся высвобождением симулятивных и деструктивных потенций, что приводит к снижению интенсивности и качества культурного развития.

Ключевые слова: сакральный опыт, культура, сакральное, профанное, религиозный, секулярный.

V. Y. Golovei, Doctor of Philosophical Science, Professor

Lesia Ukrainka Eastern European National University

13, Prospect Voli, Lutsk, 43025, Ukraine

\section{CULTURE-CREATIVE POTENTIAL OF SACRAL EXPERIENCE:} THEORETICAL AND METHODOLOGICAL ANALYSIS

The purpose of the article is to analyze the cultural potential of sacred experience and highlight the main methodological approaches to its study. The sacred experience is explicated as an experience of correlation with the absolute dimension of being, its experience and comprehension. The concept of "Sacred experience" defines a culturally organized space that acquires a specific form for each culture and is structured as a meaningful hierarchical world full of spiritual and symbolic meanings. The experience of the sacred is based on direct experience of eternity and the totality of existence as a living reality. This experience is "the experience of being" the primary expression of existential guidance, global anthropological orientation. It integrates the dominant spiritual orientation in the human world and understanding of the system itself. Sacred experience based implicitly in present most important human endeavour, promotes the formation of the humanity. This experience permeates the entire story as vertical as the Earth's axis, culminating in the transcendent dimension - where a person entrusts himself to Absolute (God, being, good, eternal, etc.). We can say that any strategy or implemented anthropological model has its core generating a sacred experience. The author asserts that the experience of Holy is distinguished by ontological content and nature. It is an experience of symbolic acts of transcendence that create ontological horizon of being. At the same time, this is an experience of cultural creation and self-creation, which forms the sense foundations of human existence, reveals and confirms the human nature. Loss of sacred power and constitutive force of the sacred dimension interpreted as a manifestation of a kind of "weakening being", de-ontologization of culture, that accompanied the release of simulative and destructive potential and leads to a decrease in the intensity and quality of cultural development

Key words: Sacral experience, culture, sacred, profane, religious, secular.

Удк 00:130.2

І. В. Живоглядова, канд. філос. наук, доц. Київський національний університет імені Тараса Шевченка вул. Володимирська, 60, м. Київ, 01033, Україна irinavictz@gmail.com

\section{МЕНТАЛЬНІСТЬ ЯК ПРЕДМЕТ МІЖДИСЦИПЛІНАРНИХ ДОСЛІДЖЕНЬ: ПРОБЛЕМА ВИЗНАЧЕННЯ}

У статті проаналізовано ментальність як суттєвий механізм культурних і суспільних процесів, підходи до визначення цього феномена. Мета статmі - реконструкція історії досліджень суспільної та гуманітарної спрямованості, які присвячені вивченню проблеми ментальності, розробці її теорії та конкретно-практичного аналізу, культурфілософфського потенціалу. Застосовуються історичний, системний, компаративний та типологічний методи аналізу. Основними висновками є: знання про ментальність різноманіттям представлених аспектів розгляду даного феномена засвідчують широту меж його прояву в різних сферах людської життєдіяльності. Дослідження своєрідності ментальності, її структури і механізмів, функціональної наповненості, діалектики взаємовідношень між духовними структурами затверджують право на самостійне існування, розкривають "людський" смисл цього феномена в якості особливого репрезентанта духовної активності людини.

Ключові слова: духовність, ментальність, менталітет, національний характер.

Постановка проблеми. В останні десятиліття питання трансформаційних змін культури і людської свідомості, відповідних можливостей міжкультурного діалогу обумовили підвищення уваги до знаходження їх дійсних механізмів і важелів. У зв'язку з цим поглиблюється розуміння того, що будь-які зрушення у сфрері реформування суспільства і держави неможливі без врахування ментальної складової культури. Від її здатності до трансформації, виходу за наявні межі залежить успіх будь-яких інновацій в економічній, політичній та інших сфрерах людського буття. Це розуміння не відкидає знання щодо темпів i неоднозначності змін у ментальних шарах, в яких історія напрацьовує і накопичує системи цінностей, звичок і вподобань, стереотипів та інерцій свідомості і які, своєю чергою, приховані під поверхнею актуального буття, визначають характер конкретної культури, її історичних шляхів.

Аналіз досліджень і публікацій. Необхідність дослідження функціонування ментальності пов'язана не тільки із запитами культурфілософської теорії на сучасному рівні її розвитку, але й з рішенням актуальних проблем, пов'язаних зі створенням і розвитком наукового дискурсу, освоєнням нових підходів, що ґрунтуються на синтезі знань різних наук - філософфії, культурології, етнології, соціальної психології, політології тощо - задля їх взаємозбагачення і доповнення.

У наш час проблемі ментальності приділяється значна увага з боку представників різних ссрер наукового знання. Питання, що стосуються даної проблема- тики, активно розробляються у сучасній психологічній, політологічній, фрілософрській, культурологічній, етнологічній, історичній, навіть в економічній і юридичній літературі. Знання про ментальність, що існують, спираються на великий фактологічний матеріал, який різноманіттям представлених аспектів розгляду даного френомена засвідчує широту меж його прояву в різних сорерах людської життєдіяльності. Ментальність і політична сфрера культури, політичний менталітет і національний характер, архетипи і коди національних політичних культур, владні та експресивні виміри в ментальності, економічна, правова ментальності 3 відповідними специфічними нормами і зразками взаємодії, організаційних і поведінкових форм, стереотипних уявлень і мотивацій - на ці питання, особливо на сучасному етапі самоідентифрікації націй і народів, знову і знову шукають відповіді як на теоретичному, так і на дієво-практичному рівнях.

Відповідно - зросла кількість розвідок як українських (О. Донченко, А. Карнаух, Ю. Романенко), так і іноземних (М. Бородіна, Д. Полєжаєв, М. Ракитянський, С. Шомова, І. Яковенко) науковців, які, звертаючись до ментального підґрунтя людської життєдіяльності, анналізують важелі і перспективи суспільно-політичної сучасності і майбутнього. Вивчається своєрідність даного феномена. I на основі аналізу його структури і механізмів, функціональної наповненості, діалектики взаємовідношень між духовними структурами затверджується

() Живоглядова І. В., 2017 